\title{
MESSAGE
}

FRoN THE

\section{PRESIDENT OF THE UNITED STATES,}

\author{
CONIIUNICATING
}

A copy of a despatch of the 12 th ultimo, addressed to the Secretary of State by the minister resident of the United States at Stockiholm, relating to an international exhibition to be held at Bergen, in Norvay, during the coming summer. .

February 14, 1865.-Read, referred to the Committee on Foreign Relations, and ordered to be printed.

\section{To the Senate and House of Representatives:}

I transmit to Congress a eopy of a despatch of the 12th ultimo, addressed to the Seeretary of State by the minister resident of the United States at Stockholm, relatiing to an international exhibition to be held at Bergen, in Norway, during the coming summer. The expediency of any legislation upon the subject is submitted for your consideration.

Washington, February $13,1865$.

ABRAHAM LINCOLN.

No. 12.]

Legation of THE UNited STATEs,

Stockholm, January 12, 1865.

Sin: I had the honor to receive your despatch (No. 10) of the 17th ultimo.

Enclosed you will please find the translated copy of a note (No.1) received by me from Count Manderstrom, of the 27th ultimo, as well as a eopy of my reply, (No. 2,) relating to an international exhibition to be lield at Bergen, Norway, next summer.

This exhibition, to which the foreign office eall my "spceial attention," will embrace fish of all kinds, from the whale to the minnow, fishing tackle, products and preservatives of fish, models of ships, boats, barrels, boxes, \&c., \&c.

This subject eannot fail to prove interesting to the fishing and trading commanities of New England, and I trust the enterprise and ingenuity of my comtrymen will contribute to the attraction of the oceasion.

It is desired by those having the matters in charge that public attention in the United States may be called to their enterprise. I enelose copies of the programme, with a translation of the same.

I have the honor to be, with great respect, your obedient servant,

Hon. William H. Seward, 


\section{[Translation.]}

No. 1.]

Stockholm, December 27, 1864.

Sir: I have the honor to call your special attention to the international exhibition of the products of fish and fishing tackle, as well as other objects employed in fishing, which will take place at Bergen, Norway, from the 1st of August to the 16th of September, 1865, an exhibition of which I have the honor to transmit you herewith the programme. tion.

Be pleased to accept, sir, the assurance of my most distinguished considera-

\section{Mr. CAMPBELL, \\ Minister Resident of the United States of America, \&c., \&c., \&c. \\ MANDERSTROM.}

No. 2.]

Legation of the United States, Stoctiholm, January 11, 1865.

Sir : I had the honor to receive the note of your excellency of the 27 th ultimo. calling my attention to an international exhibition to be held at Bergen, Norway, in the course of next summer, relating to fish and fisheries.

The branches of industry embraced within the purview of the programme you did me the honor to enclose have added much to the wealth and prosperity of the New England States of my own country, as well as to the United Kingdom of Siveden and Norway.

The exhibition cannot fail to be of importance and interest to the people of both countries, and I shall take pleasure in calling the especial attention of my government to a purpose so interesting.

This occasion is embraced by me, sir, to present the assurance of my most distinguished consideration.

His Excellency Count Mandfrstrom,

JAIIES H. CAMPBELL.

Minister of State and of Froreign Affairs, \&c., \&c., \&c.

\section{[Translation.]}

Programme of an international exhibition of products and apparatus of fishing, as well as other things used in fishing, which. will be held at Bergen, Norway, from the first day of August until the sixteenth day of September, $A$. D. 1865 .

This exhibition, suggested by the initiative of the common council of Bergen, and supported by the royal government of Norway, has for its object the introduction to the public of the different products of fisheries, and the means of improving fisheries, and the branches of labor which appertain thereto, in different countries. Like that which was held at Amsterdam in 1861, this exhibition will comprehend :

1. All kinds of fish in the sea, from the whale and seal to the smallest fish of the shores.

2. All kinds of fish in the gulfs, bays, mouths of streams, and rivers.

3. All kinds of fish of the lakes, streams, rivers, and canals.

4. The artificial increase of sea and fresh-water' fish.

As to the different kinds of fish they will receive at the exhibition :

A. Products of fish of all kinds, alimentary, as well as those used for agriculture and industrial purposes. 
B. Instruments used in preparing fish, namely, to remove the gills, cut up the fish, Ec., or models of such instruments.

C. Models and drawings of ships, or of the appointments in which or by the aid of which the fish are prepared, that is to say, smoked, steamed, dried, \&ce.

D. Substances used to preserve fish, such as salt, pickles, \&c.

E. Instruments used to pack and transport the products of fisheries, such as barrels, baskets, boxes, \&c.

F. Ships and boats of all kinds employed in fishing, and all the rigging on the different parts eomposing it.

G. Models of objects mentioned under letter $\mathrm{F}$..

H. All things used to equip a fishing vessel, such as barrels, baskets, and articles used to preserve fish, bait, \&ce.

I. 'Tackle of all kinds used in fishing, in every acceptation of the term, as well the materials used in their manufacture, as instruments to make fishing lines, oak bark, and other preservatives of fishing tackle.

K. Artificial bait and all which serves to prepare and preserve natural bait.

L. Models of the habitations of fishermen, be they houses or ships in the fisheries, as well as provisions and articles of dress.

M. Popular works upon the improvement of fish.

'I'o organize the exhibition, and to preside over it, the common council of Bergen has nominated a commission composed of the undersigned members. In consequeuce, we have the honor to invite amateurs, fishermen, merchants, and artisans, who will have the goodness to send articles to the exhibition, to address themselves by writing until the first of July next to the commission of the interuational exhibition of fishery, Bergen, Norway. (See names on printed programme.)

Platon Bonrgmestre, president; Ege, president du conseil municipal; Peter Blytt, négociant; Christen K. Gran, consul; T. J. Loberg, médecin en chef; Gottleib Thomsen, négociant, cassier; Hth. Meinich, préfet; D. C. Danielssen, médecin en chef; J. Koren, médecin; Anton P. Mohr, consul; D. C. Stoliz.

Cordier : Herman Baars, négociant, secrétaire ; J. A. Michelsen, consul, membre du syndicat de la bourse; $A$. Dekke, construeteur de navires; Herm. C. Lehmkuhl, négociant; Randulph Nilsen, fabricant de voiles.

C. VON TANGEN, Négosiant. 
